\title{
Thermal stability for the effective use of commercial catalase
}

\author{
J. Miłek ${ }^{1}$, M. Wójcik ${ }^{1}$ W. Verschelde ${ }^{2}$ \\ ${ }^{1}$ University of Technology and Life Sciences, Department of Chemical and Biochemical Engineering, Faculty of Chemical \\ Technology and Engineering, Seminaryjna 3, 85-326 Bydgoszcz, Poland \\ ${ }^{2}$ Faculty of Industrial Engineering, KaHo St.Lieven, Gebroeders Desmetstraat 1, 9000 Gent, Belgium \\ "Corresponding author: e-mail: jmilek@utp.edu.pl
}

\begin{abstract}
Catalase with the commercial catalase name Terminox Ultra is widely used in the textile industry in bleaching processes. This enzyme is used to catalyse the decomposition of residual hydrogen peroxide into oxygen and water. In this study catalase was kept for about 30 hours in water baths in a temperature range from 35 to $70^{\circ} \mathrm{C}$. For the first time, the kinetics of thermal deactivation of this enzyme was examined using an oxygen electrode. Stability of the enzyme depends strongly on temperature and its half-life times are $0.0014 \mathrm{~h}$ and $7.6 \mathrm{~h}$, at 35 and $70^{\circ} \mathrm{C}$, respectively.
\end{abstract}

Keywords: catalase, Terminox Ultra, thermal deactivation, energy of thermal deactivation, hydrogen peroxide.

\section{INTRODUCTION}

The consumption of hydrogen peroxide in commercial processes and waste treatment has been growing fast recently. In the textile industry, hydrogen peroxide is used for bleaching a majority of natural and artificial fibers ${ }^{\mathbf{1}, 2}$. Hydrogen peroxide is applied in the pulp and paper industry, and for delignification and bleaching of cellulose pulp. It is also applied in food processing and in the pharmaceutical industry as a bactericidal disinfectant. Hydrogen peroxide is also used as a raw material for obtaining a range of organic and inorganic peroxides, which can be utilized as disinfectants and as an initiator for polymerization reactions, etc. In a majority of cases, it is necessary to eliminate any residual hydrogen peroxide. Conventional chemical methods have many drawbacks. Traditionally, they make use, for instance, of metals oxides, active carbon, and by increased temperatures they can lead to the formation of undesirable side products. The use of catalase for decomposition of hydrogen peroxide into oxygen and water may be an alternative. Catalase is used, for instance, in the textile industry ${ }^{3}$, in food processing ${ }^{4,5}$ and in the manufacturing of semi-conductors. Moreover, the enzyme is indispensable in carrying out biotransformation processes with the use of oxidases to cause decomposition of hydrogen peroxide being formed in the reaction ${ }^{6}$.

For the first time, catalase has been isolated in its crystalline form from beef liver ${ }^{7}$. Since then, it has been the object of numerous investigations ${ }^{8-10}$. Microbial catalase (for example catalase isolates from fungus Scytalidium thermophilum), is applied for commercial purposes because of its higher stability in conditions of extreme $\mathrm{pH}$, temperature and $\mathrm{H}_{2} \mathrm{O}_{2}$ content. Like bovine catalase, it is tetrametrical, consisting of four sub-units, with four atoms $\mathrm{Fe}^{\mathrm{III}}$. However, catalase Scytalidium thermophilum differs from bovine catalase by considerably larger molecules, compared with beef catalases, and the molecular mass of their sub-units amounts to $80-97 \mathrm{kDa}$.

In the textile industry, catalase with the commercial name Terminox Ultra is used for decomposition of hydrogen peroxide.

$2 \mathrm{H}_{2} \mathrm{O}_{2} \stackrel{\text { catalase }}{\longrightarrow} \mathrm{O}_{2}+2 \mathrm{H}_{2} \mathrm{O}$

The catalytic reaction takes place in two steps. The first hydrogen peroxide molecule oxidizes the heme to form an oxyferryl species in which one oxidation equivalent is removed from the iron and one from the porphyrin ring to generate a porphyrin cation radical (reaction 2). The second hydrogen peroxide is then used as a reactant of compound $\mathrm{I}-\mathrm{Enz}\left(\mathrm{Por}^{+\bullet}-\mathrm{Fe}^{\mathrm{IV}}=\mathrm{O}\right)$ to regenerate the resting state enzyme, water, and oxygen (reaction (3) ${ }^{11}$. $\mathrm{Enz}\left(\right.$ Por $\left.-\mathrm{Fe}^{\mathrm{III}}\right)+\mathrm{H}_{2} \mathrm{O}_{2} \rightarrow \mathrm{H}_{2} \mathrm{O}+\mathrm{Enz}\left(\right.$ Por $\left.^{+\bullet}-\mathrm{Fe}^{\mathrm{IV}}=\mathrm{O}\right)$ (2) $\mathrm{Enz}\left(\right.$ Por $\left.{ }^{*}-\mathrm{Fe}^{\mathrm{IV}}=\mathrm{O}\right)+\mathrm{H}_{2} \mathrm{O}_{2} \rightarrow \mathrm{H}_{2} \mathrm{O}+\mathrm{O}_{2}+\mathrm{Enz}\left(\mathrm{Por}-\mathrm{Fe}^{\mathrm{III}}\right)(3)$

A catalase with the commercial name Terminox Ultra is produced from the fungus Scytalidium thermophilum ${ }^{12}$. This kind of catalase is a concentrated product in the form of a brown liquid meant to be diluted. The application of the enzyme in the textile industry has the following advantages: it reduces the waste of energy by about $48 \%$, it reduces the costs of chemical agents with about $83 \%$, it lowers the waste of water by about $50 \%$, and it reduces the process time by about $33 \%$ in comparison with the decomposition process of $\mathrm{H}_{2} \mathrm{O}_{2}$ without the use of catalase ${ }^{2}$.

During the decomposition of hydrogen peroxide by catalase, usually deactivation of the enzyme by the substrate is dominant ${ }^{3,5,13,14}$. Nevertheless, at low concentrations of hydrogen peroxide and at temperatures above $35^{\circ} \mathrm{C}$, the thermal deactivation could also be important.

The kinetics of thermal deactivation for the catalase with the commercial name Terminox Ultra, according to our best knowledge; has not been the object of systematic research so far. The objective of the present work is to study the influence of temperature on the enzyme's deactivation.

\section{EXPERIMENTAL}

\section{Material}

Catalase (E.C. 1.11.1.6) Terminox Ultra 50L (activity $50000 \mathrm{U} / \mathrm{ml}$ ) from Novozymes, Denmark. Perhydrol (30\% hydrogen peroxide from POCH, Gliwice). All other chemicals used were of analytical purity.

\section{Thermal deactivation}

For the present study, hydrogen peroxide has been prepared at an initial concentration of $0.01 \mathrm{M}$ and a solution of the enzyme in the proportion 1:1000 
(enzyme : phosphate buffer). The experiments were carried out keeping the enzyme for $30 \mathrm{~h}$ in a water bath at a temperature in the range $35-70^{\circ} \mathrm{C}$. The activity of catalase was examined using an oxygen electrode method $^{15,16}$.

The catalase activity was assayed in the temperature range from 35 to $50^{\circ} \mathrm{C}$ after incubation times between 0 and $30 \mathrm{~h}$. Thermal deactivation occurred rapidly at higher temperatures. For this reason, for an incubation temperature of $55-60^{\circ} \mathrm{C}$ catalase activity was tested after a time in the range from 0 to $25 \mathrm{~h}$, and for an incubation temperature in the range from 65 to $70^{\circ} \mathrm{C}$ catalase activity was tested after a time between 0 and $6 \mathrm{~h}$.

\section{Method to measure the activity of catalase}

The catalase activity was determined by measuring the rate of oxygen production in a $150 \mathrm{ml}$ Erlenmeyer flask fitted with a dissolved oxygen sensor for the quantification of dissolved oxygen. The Erlenmeyer flask was placed in a thermostated water jacket and its contents was stirred by means of a magnetic stirrer.

After introducing $100 \mathrm{ml}$ of $0.01 \mathrm{M}$ hydrogen peroxide solution in $0.02 \mathrm{M}$ phosphate buffer $(\mathrm{pH} 7)$ and obtaining a temperature of $20^{\circ} \mathrm{C}$ in the $\mathrm{H}_{2} \mathrm{O}_{2}$ solution, desorption of oxygen by means of $\mathrm{N}_{2}$ was performed.

Measurements of catalase activity were initiated by injecting a $0.1 \mathrm{ml}$ catalase solution into the reaction vessel and data were collected within $150 \mathrm{sec}$.

Based on the results of measurements, the concentration of oxygen in the reaction solution was determined in $\mu \mathrm{M}$. By means of a graphic presentation of the concentration of $\mathrm{O}_{2}$ being generated in time, the rate of formation of $\mathrm{O}_{2}$ was found in $\mu \mathrm{M} / \mathrm{s}$ from a tg of the angle of inclination of the straight line. The activity of catalase was found in accordance with the above procedure for the consecutive samples collected after some time of residence at a suitable temperature in the range from 35 to $70^{\circ} \mathrm{C}$. The one unit of activity of catalase was defined as the quantity of $\mu \mathrm{M}$ of $\mathrm{O}_{2}$ being generated per second, in relation to the time of residence at a specific temperature. The catalase activity was normalized in relation to the initial activity for the purpose of comparison of the changes in activity for a whole range of temperatures from 35 to $70^{\circ} \mathrm{C}$.

Considering the wide range of temperatures in which thermal deactivation was studied, the time of measurement was a max. of $150 \mathrm{~s}$. It was observed that the influence of oxygenation as a result of diffusion of oxygen from the air was negligible.

\section{Kinetic model}

The thermal deactivation process of enzymes could follow a single-step mechanism or a more complicated multi-step mechanism. The kinetics of thermal deactivation of catalase ${ }^{\mathbf{1 6 - 1 9}}$ can be described as a first order kinetics equation:

$\frac{\mathrm{da}}{\mathrm{dt}}=-\mathrm{k}_{\mathrm{D}} \mathrm{a}$

where $\mathrm{a}=\mathrm{C}_{\mathrm{E}} / \mathrm{C}_{\mathrm{E} 0}$ is the dimensionless activity of catalase, which has an initial value $\mathrm{a}=1$ for $\mathrm{t}=0$. Integration of Equation (4) gives

$\mathrm{a}=\exp \left(-\mathrm{k}_{\mathrm{D}} \mathrm{t}\right)$ that expresses changes in the enzyme's activity as a function of time.

The thermal deactivation constant $\mathrm{k}_{\mathrm{D}}$ depends on temperature, and the Arrhenius equation was applied to describe the relationship:

$\mathrm{k}_{\mathrm{D}}=\mathrm{k}_{\mathrm{D} 0} \exp \left(-\frac{\mathrm{E}_{\mathrm{D}}}{\mathrm{RT}}\right)$

An important practical problem is to determine the constants in Equation (6). The calculation of $\mathrm{k}_{\mathrm{D}}$ and $E_{D}$ using the logarithmic form arouses much controversy ${ }^{\mathbf{2 0 - 2 3}}$ with regard to the strong correlation between the parameters $\mathrm{k}_{\mathrm{D}}$ and $\mathrm{E}_{\mathrm{D}}$. To decrease the correlation among the parameters in Equation (6), the reference temperature $\mathrm{T}_{\text {ref }}{ }^{22}$ is introduced and Equation (6) takes the following form:

$\mathrm{k}_{\mathrm{D}}=\mathrm{k}_{\mathrm{D}, \text { Tref }} \exp \left[\frac{\mathrm{E}_{\mathrm{D}}}{\mathrm{R}}\left(\frac{1}{\mathrm{~T}_{\text {ref }}}-\frac{1}{\mathrm{~T}}\right)\right]$

Taking into account Equation (7), the change of activity of the enzyme can be described by the following expression:

$a_{i}=\exp \left[-k_{D, \operatorname{Tref}} \exp \left[\frac{E_{D}\left(T_{j}-T_{\text {ref }}\right)}{R T_{j} T_{\text {ref }}}\right] t_{i}\right]$

where:

$\mathrm{i}$ - number of measurements $(0,1,2 \ldots n)$,

$\mathrm{T}_{\mathrm{j}}$ - temperature at which the measurement was carried out $[\mathrm{K}]$,

$\mathrm{T}_{\text {ref }}$ - reference temperature determined by Schwab and Pinto 22 .

Based on Equation (8) the values of $\mathrm{k}_{\mathrm{D} \text {,Tref }}$ and $\mathrm{E}_{\mathrm{D}}$ were found using nonlinear regression - the Levenberg-Marquardt procedure ${ }^{24-27}$. It is a standard technique used for solving nonlinear equations by the least squares method and is the most popular alternative to the Gauss-Newton method for finding the minimum of a function that is a sum of the squares:

$\operatorname{SSE}\left(E_{D}, k_{D, T r e f}\right)=\sum_{i=}^{n}\left(\left(a_{\text {exp. }}\right)_{i}-a_{\text {cal. }}\left(E_{D}, k_{D, \text { Tref }}, t_{i}, T_{j}, T_{\text {ref }}\right)\right)^{2}$

where: $\left(\mathrm{a}_{\mathrm{exp}}\right)_{\mathrm{i}}$ - enzyme activity, as determined experimentally,

$\mathrm{a}_{\text {cal. }}\left(\mathrm{E}_{\mathrm{D}}, \mathrm{k}_{\mathrm{D}, \text { Tref }}, \mathrm{t}_{\mathrm{i}}, \mathrm{T}_{\mathrm{j}}, \mathrm{T}_{\text {ref }}\right)$ - enzyme activity, as calculated from Equation (8).

Most often nonlinear regression is applied, giving equal weights to all points (Equation 9). If experimental scatter is expected to vary along the curve, then the points should be weighted_differentially. The most often used weighting method is called "weighting by $1 / y^{2}$ " and, in this case, is described as follows:

$\operatorname{SSE}\left(\mathrm{E}_{\mathrm{D}}, \mathrm{k}_{\mathrm{D}, \text { Tref }}\right)=\sum_{\mathrm{i}=0}^{\mathrm{n}} \frac{1}{\left(\mathrm{a}_{\text {exp. }}\right)_{\mathrm{i}}{ }^{2}}\left(\left(\mathrm{a}_{\text {exp. }}\right)_{\mathrm{i}}-\mathrm{a}_{\text {cal. }}\left(\mathrm{E}_{\mathrm{D}}, \mathrm{k}_{\mathrm{D}, \text { Tref }}, \mathrm{t}_{\mathrm{i}}, \mathrm{T}_{\mathrm{j}}, \mathrm{T}_{\text {ref }}\right)\right)^{2}$

Equation (10) allows to find a solution to the objective function with a given set of parameters. The global minimum of the objective function was determined from many local minima in the parameter estimation process. 


\section{RESULTS AND DISCUSSION}

The obtained values of the parameters in Equation (8) are calculated using nonlinear regression with SigmaPlot 11.0 and represented in Table 1.

Table 1. Parameters of thermal deactivation for catalase

\begin{tabular}{|c|c|c|}
\hline $\mathrm{T}_{\text {ref }}[\mathrm{K}]$ & $\mathrm{k}_{\mathrm{D}, \text { Tref }}\left[\mathrm{h}^{-1}\right]$ & $\mathrm{E}_{\mathrm{D}}\left[\mathrm{kJ} \cdot \mathrm{mol}^{-1}\right]$ \\
\hline 331.6 & $0.0732 \pm 0.0004$ & $140.93 \pm 0.63$ \\
\hline
\end{tabular}

The Pearson correlation coefficient $r$ for the obtained parameters was 0.9994 and the determination coefficient (correlation coefficient squared, $\mathrm{r}^{2}$ ) was 0.9988 , however, the standard error of estimation was equal to 0.0291 .

Having at one's disposal the constants of thermal deactivation for catalase $\mathrm{k}_{\mathrm{D} \text {,Tref }}$ and of $\mathrm{E}_{\mathrm{D}}$ at a reference temperature calculated with the transformed Arrhenius equation, it is possible to calculate the value of the pre-exponential thermal deactivation rate constant for catalase: $1.1562 \cdot 10^{21} \mathrm{~h}^{-1}$.

Figure 1 shows the experimental data of the change of activity of catalase for temperatures in the range from 35 to $70^{\circ} \mathrm{C}$, enabling them to be compared with the values of the change of activity of catalase calculated using the data from Table 1.

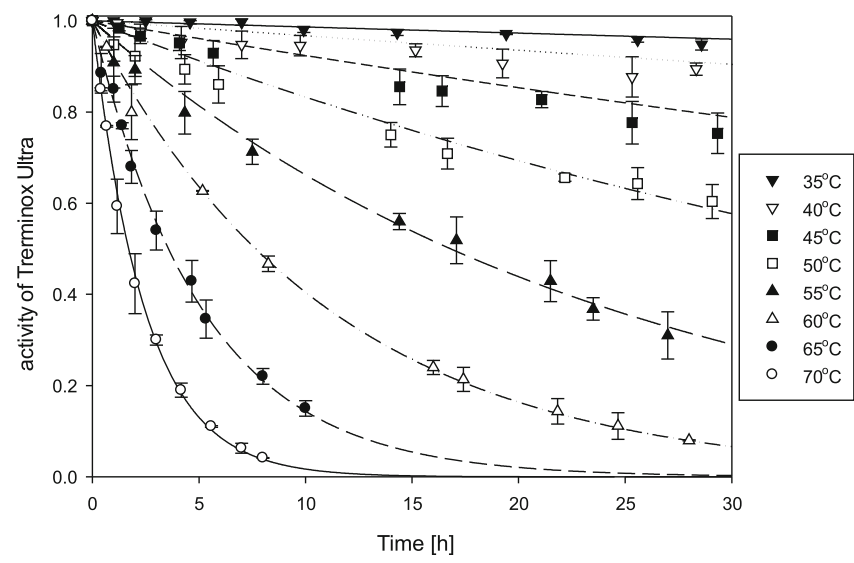

Figure 1. Effect of temperature on the change of activity as a function of time for the thermal deactivation of catalase

The first-order model is able to adequately fit all the kinetic data at all temperatures. At $70^{\circ} \mathrm{C}$, the catalase is rapidly deactivated to about $5 \%$ of its initial activity within an incubation time of $8 \mathrm{~h}$, while almost all of the initial activity of the enzyme remains for catalase in the identical incubation time at $35^{\circ} \mathrm{C}$. Catalase showed a decrease in activity of about $4 \%$ when it was kept at $35^{\circ} \mathrm{C}$ for $30 \mathrm{~h}$.

The activity of catalase at specific times and temperatures was calculated using Equations (8) with the estimated parameters from Table 1.

Figure 2 shows the comparison between the experimental and the calculated data for activity. Figure 3 shows the residual analysis results for temperatures in the range from 35 to $70^{\circ} \mathrm{C}$.

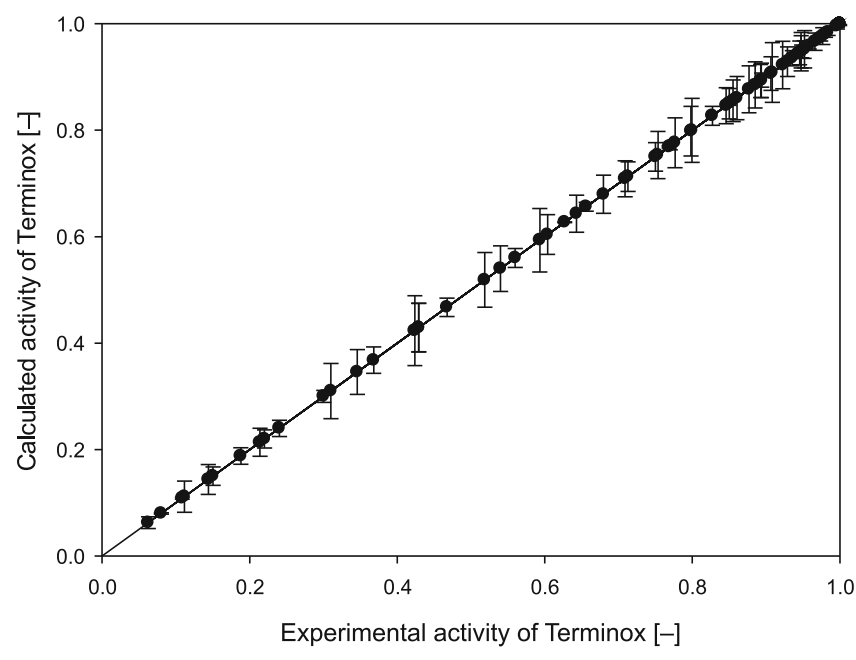

Figure 2. Comparison between the experimental and calculated data for the activity of catalase

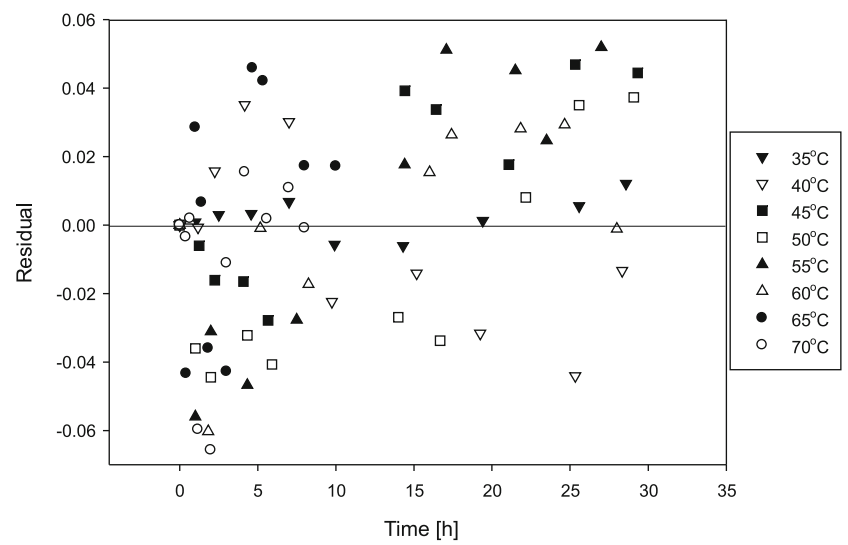

Figure 3. Residual analysis results at temperatures in the range from $35^{\circ} \mathrm{C}$ to $70^{\circ} \mathrm{C}$

A regular distribution of residuals without any patterns is observed, indicating the adequacy of the estimated parameters.

The residual analysis results presented in Figure 3 were in the range of \pm 0.07 but the value of average absolute residuals was equal to $2.32 \cdot 10^{-4}$. The accomplished statistical analyses at specific temperatures in the range from 35 to $70^{\circ} \mathrm{C}$ for catalase confirm that the assumption of a first-order kinetics is well-founded.

Enzyme stability is often expressed as half-life time $\left(t_{1 / 2}\right)$ at defined temperatures. The half-life $t_{1 / 2}$ for the decrease of activity of the catalase Terminox Ultra is described by the following relationship:

$\mathrm{t}_{1 / 2}=\frac{\ln 2}{\mathrm{k}_{\mathrm{D}}}$

Properties such as the thermal deactivation constants $\left(\mathrm{k}_{\mathrm{d}}\right)$ and the half-life times $\left(\mathrm{t}_{1 / 2}\right)$ were determined and are presented in Table 2 .

The value of half-life time at a temperature of $35^{\circ} \mathrm{C}$ is approximately 280 times as high as those at $70^{\circ} \mathrm{C}$.

Table 2. Kinetic parameters for the thermal inactivation of catalase with the commercial name Terminox Ultra

\begin{tabular}{|l|c|c|c|c|c|c|c|c|}
\hline Temperature $\left[{ }^{\circ} \mathrm{C}\right]$ & 35 & 40 & 45 & 50 & 55 & 60 & 65 & 70 \\
\hline $\mathrm{k}_{\mathrm{D}}\left[\mathrm{h}^{-1}\right]$ & 0.0014 & 0.0035 & 0.0082 & 0.0188 & 0.0418 & 0.0908 & 0.1930 & 0.4008 \\
\hline $\mathrm{t}_{1 / 2}[\mathrm{~h}]$ & 474 & 197 & 84 & 37 & 16.6 & 7.6 & 3.6 & 1.7 \\
\hline
\end{tabular}


Half-life time activities for catalase with the commercial name Terminox Ultra are shown only in two papers ${ }^{3,28}$. Costa presented half-life time only for the temperatures of $30^{\circ} \mathrm{C}^{3}$ and $37^{\circ} \mathrm{C}^{28}$. Figure 4 shows the comparison of half-life time $t_{1 / 2}$ for catalase as reported in the literature and as calculated from Equation (10).

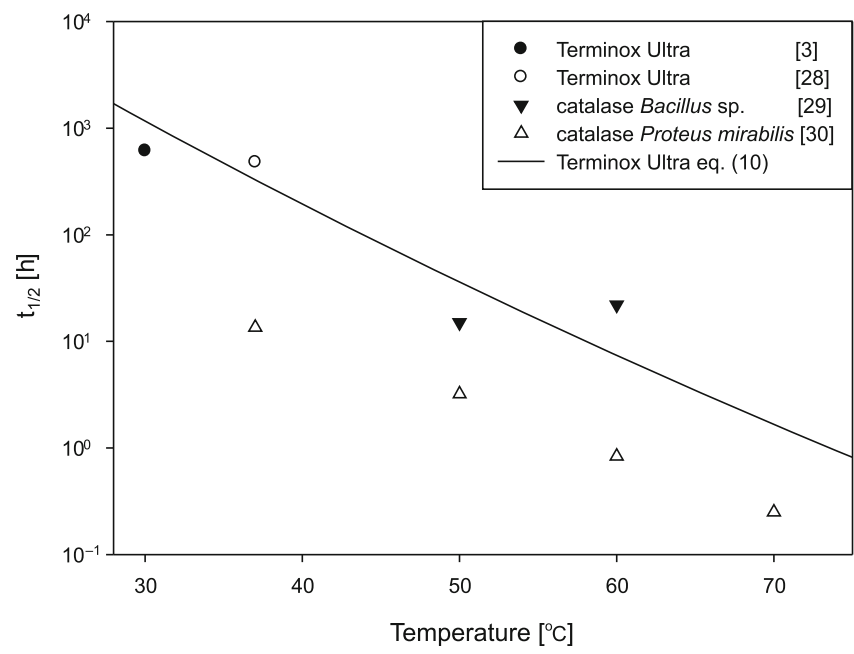

Figure 4. Comparison between the half-life times $t 1 / 2$ for catalase in the literature and as calculated according to Equation (10)

From Figure 4 it appears, that the values of half-life time of a decrease in activity, calculated for the catalase Terminox Ultra, are in the range of values for $t_{1 / 2}$ determined by other researchers. The results are different when enzymes of various origins are used. Although catalases, which are produced by most aerobic microorganisms, are very well studied enzymes, there are few reports on the half-life time $t_{1 / 2}$ for thermostable catala$\mathrm{se}^{29,30}$. Figure 4 also shows half-life time $t_{1 / 2}$ for catalases from the thermostable bacterium: Bacillus sp. $^{29}$ which is isolated from a textile wastewater drain and Proteus mirabilis $^{\mathbf{3 0}}$. At a $\mathrm{pH}$ of 7.0 and at temperatures 37, 50, 60 and $70^{\circ} \mathrm{C}$, half-life time $\mathrm{t}_{1 / 2}$ for catalase from Proteus mirabilis $^{\mathbf{3 0}}$ showed values which were approximately eight times as low as that for the enzyme with commercial name Terminox Ultra.

There are more reports in the literature about the bovine liver catalase, which has the longest history. Jürgen-Lohmann and Legge ${ }^{19}$ proposed that constant thermal deactivation rates could be established at temperatures in the range from 40 to $65^{\circ} \mathrm{C}$. A comparison between the half-life time values for bovine catalase ${ }^{\mathbf{1 9}}$ and those for the catalase studied in this work is shown in Table 3.

Table 3. Comparison between the half-life time values for bovine catalase and those for the catalase studied in this work

\begin{tabular}{|l|c|c|}
\hline $\begin{array}{l}\text { Temperature } \\
{\left[{ }^{\circ} \mathrm{C}\right]}\end{array}$ & $\begin{array}{c}\mathrm{t}_{1 / 2}[\mathrm{~h}] \\
\text { for bovine } \\
\text { catalase }\end{array}$ & $\begin{array}{c}\mathrm{t}_{1 / 2}[\mathrm{~h}] \\
\text { for catalase } \\
\text { Terminox Ultra }\end{array}$ \\
\hline 40 & 0.58 & 194 \\
55 & 0.38 & 16 \\
60 & 0.10 & 7.4 \\
65 & 0.03 & 3.5 \\
\hline
\end{tabular}

From Table 3, it is obvious that the half-life time values for the catalase used in this work are 40 to 340 times as high as those for bovine catalase. The values of activation energy for the thermal deactivation reaction for catalase with the commercial name Terminox Ultra are over 1.5 times as high as those determined for bovine catalase ${ }^{\mathbf{1 9}}$.

The obtained results confirm the universally acceptable opinion that a catalase of microbiological origin is more stable than the bovine catalase.

\section{CONCLUSIONS}

It was found that the thermal deactivation of catalase proceeded according to a first order kinetics. This consideration is validated by an accordance between the measured and the calculated values. Thermal deactivation rate constants varied depending on temperature, in accordance with the Arrhenius equation. Activation energy for the thermal deactivation process of the catalase with the commercial name Terminox Ultra was $140.93 \pm 0.63 \mathrm{~kJ} \cdot \mathrm{mol}^{-1}$.

The parameters obtained for the enzyme can be used in the modeling and optimization of batch bioreactors ${ }^{31-33}$. Optimal temperature control enables a reduction of reaction time lowering the costs in comparison with an isothermal process ${ }^{34}$. Additionally, the presented methodology of measurement can be used for determining the half-life time of commonly used catalases, which are less stable than catalase with the commercial name Terminox Ultra.

\section{APPENDIX A}

Table 4. Definitions of symbols where fixed (except where otherwise given in the text)

\begin{tabular}{|c|c|}
\hline Symbol & Definition \\
\hline$\left(a_{\text {exp. }}\right)_{i}$ & Enzyme activity determined experimentally \\
\hline$a_{\text {cal. }}$ & Enzyme activity calculated on the basis of eq. (8). \\
\hline $\mathrm{C}_{\mathrm{E}}$ & Concentration of enzyme $\left[\mathrm{mol} \cdot \mathrm{dm}^{-3}\right]$ \\
\hline $\mathrm{C}_{\mathrm{E} 0}$ & Concentration of enzymein initial time $\mathrm{t}=0[\mathrm{M}]$ \\
\hline$E_{D}$ & $\begin{array}{l}\text { Activation energy for thermal deactivation } \\
{\left[\mathrm{kJ} \cdot \mathrm{mol}^{-1}\right]}\end{array}$ \\
\hline $\mathrm{k}_{\mathrm{D}}$ & Thermal deactivation rate constant $\left[\mathrm{h}^{-1}\right]$ \\
\hline $\mathrm{k}_{\mathrm{D}, \mathrm{T}_{\text {ref }}}$ & $\begin{array}{l}\text { Thermal deactivation rate constant in reference } \\
\text { temperature }\left[\mathrm{h}^{-1}\right]\end{array}$ \\
\hline $\mathrm{k}_{\mathrm{DO}}$ & $\begin{array}{l}\text { Pre-exponential thermal deactivation rate } \\
\text { constant }\left[\mathrm{M}^{-1} \cdot \mathrm{h}^{-1}\right]\end{array}$ \\
\hline $\mathrm{k}_{\mathrm{R}}^{*}=\mathrm{C}_{\mathrm{E} 0} \mathrm{k}_{\mathrm{R}}$ & Apparent rate constant $\left[\mathrm{M}^{-1} \cdot \mathrm{h}^{-1}\right]$ \\
\hline $\mathrm{k}_{\mathrm{R}}$ & Rate constant $\left[\mathrm{M}^{-1} \cdot \mathrm{h}^{-1}\right]$ \\
\hline $\mathrm{R}$ & Gas constant $\left[\mathrm{J} \mathrm{mol}^{-1} \cdot \mathrm{K}^{-1}\right]$ \\
\hline $\mathrm{T}$ & Temperature [K] \\
\hline$T_{j}$ & $\begin{array}{l}\text { Temperature at which the measurement was } \\
\text { executed }[\mathrm{K}]\end{array}$ \\
\hline $\mathrm{T}_{\text {ref }}$ & Referencetemperature [K] \\
\hline $\mathrm{t}$ & Time [h] \\
\hline$t_{1 / 2}$ & Timeof half-life activity of enzyme (h) \\
\hline
\end{tabular}

\section{ACKNOWLEDGMENT}

The authors wish to thank the Polish Ministry of Science and Higher Education for its financial support.

\section{LITERATURE CITED}

1. Eren, H.A., Anis, P. \& Davulcu, A. (2009). Enzymatic Onebath Desizing-Bleaching - Dyeing Process for Cotton Fabrics. Text. Res. J. 79, 1091-1098. DOI: 10.1177/0040517508099388.

2. Nielsen, P.H., Kuilderd, H., Zhou W. \& Lu, X. (2009). Enzyme biotechnology for sustainable textiles. In Blackburn, R.S. 
(Eds), Sustainable textiles. Life cycle and environmental impact. (pp.113-138). Woodhead Publishing in Textiles No.98 http:// www.novozymes.com/en/sustainability/Published-LCAstudies/ Documents/Enzyme\%20biotechnology\%20for\%20sustainable\%20textiles.pdf

3. Costa, S.A., Tzanov, T., Carneiro, A.F., Gübitz, G.M. \& Cavaco-Paula, A. (2002). Recycling of textile bleaching effluents for dyeing using immobilized catalase. Biotechnol. Lett. 24(3), 173-176. DOI: 10.1023/A:1014136703369.

4. Tarhan, L. (1995). Use of immobilized catalase to remove $\mathrm{H}_{2} \mathrm{O}_{2}$ used in the sterilization of milk. Proc. Biochem. 30(7), 623-628. DOI: 10.1016/0032-9592(94)00066-2.

5. Akertek, E. \& Tarhan, L. (1995). Characterization of immobilized catalases and their application in pasteurization of milk with $\mathrm{H}_{2} \mathrm{O}_{2}$. Appl. Biochem. Biotechnol. 50(3), 291-303. DOI: $10.1007 / \mathrm{BF} 02788099$.

6. Fernández-Lafuente, R., Rodriguez, V. \& Guisán, J.M. (1998). The coimmobilization of d-amino acid oxidase and catalase enables the quantitative transformation of d-amino acids (d-phenylalanine) into $\alpha$-keto acids (phenylpyruvic acid). Enz. Microb. Technol. 23(1-2), 28-33. DOI: 10.1016/S0141-0229(98)00028-3.

7. Sumner, J.B. \& Dounce, A.I. (1937). Crystalline catalase. J. Biol. Chem. 121, 417-427. http://www.jbc.org/content/121/2/417. full.pdf + html

8. Yoshimoto, M., Sakamoto, H., Yoshimoto, N., Kuboi, R. \& Nakao, K. (2007). Stabilization of quaternary structure and activity of bovine liver catalase through encapsulation in liposomes. Enz. Microb. Technol. 41, 849-858. DOI:10.1016/j. enzmictec.2007.07.008.

9. Na, W., Wei, Q., Sun, H. \& Nie, Z.R. (2013). Catalase immobilized on siliceous mesocellular foam with controlled window size. J. Porous Materials 20(1), 75-79. DOI: 10.1007/ s10934-012-9576-z.

10. Doğaç, Y.İ. \& Teke, M. (2013). Immobilization of bovine catalase onto magnetic nanoparticles. Prep. Biochem. Biotechnol. 43(8), 750-765. DOI: 10.1080/10826068.2013.773340.

11. Switala, J. \& Loewen, P.C. (2002). Diversity of properties among catalases. Arch. Biochem. Biophys. 401, 145-154. DOI: 10.1016/s0003-9861(02)00049-8.

12. Kaasgaard, S. (2008). European Patent No. 1,718,724 B1. European Patent Office.

13. Miłek. J. \& Wójcik, M. (2011). Effect of temperature on the decomposition of hydrogen peroxide by catalase Terminox Ultra. Przem. Chem. 90(6), 1260-1263. http:// sigma-not.pl/publikacja-60227-wplyw-temperatury-na-rozkladnadtlenku-wodoru-przez-katalaze-terminox-ultra-przemyslchemiczny-2011-6.html (abstract in Polish).

14. Raducan, A., Cantemir, A.R., Puiu, M. \& Oancea, D. (2012). Kinetics of hydrogen peroxide decomposition by catalase: hydroxylic solvent effects. Bioprocess Biosyst. Eng. 35(9), 1523-1530. DOI: 10.1007/s00449-012-0742-0.

15. Hakala, M., Rantamaki, S., Puputti, E.M., Tyystjarvi, T. \& Tyystjarvi, E. (2006). Photoinhibition of manganese enzymes: insights into the mechanism of photosystem II photoinhibition. J. Exp. Bot. 57(8), 1809-1816. DOI: 10.1093/jxb/erj189.

16. Díaz, A., Muñoz-Clares, R.A., Rangel, P., Valdés, V.J. \& Hansberg, W. (2005). Functional and structural analysis of catalase oxidized by singlet oxygen. Biochimie 87 , 205-214. DOI: 10.1016/j.biochi.2004.10.014.

17. Cantemira, A.R., Raducana, A., Puiub, M. \& Oancea, D. (2013). Kinetics of thermal inactivation of catalase in the presence of additives. Proc. Biochem. 48, 471-477. DOI: 10.1016/j. procbio.2013.02.013.

18. Oancea, D., Stuparu, A., Nita, M., Puiu, M. \& Raducan, A. (2008). Estimation of the overall kinetic parameters of enzyme inactivation using an isoconversional method. Biophys. Chem. 138, 50-54. DOI: 10.1016/j.bpc.2008.09.003.
19. Jürgen-Lohmann, D.L. \& Legge, R.L. (2006). Immobilization of bovine catalase in sol - gels. Enz. Microb. Technol. 39, 626-633. DOI: 10.1016/j.enzmictec.2005.11.015.

20. Brauner, N. \& Shacham, M. (1997). Statistical analysis of linear and nonlinear correlation of the Arrhenius equation constants. Chem. Eng. Proc. 36(3), 243-249. DOI: 10.1016/ S0255-2701(96)04186-4.

21. Rodionova, O.E. \& Pomerantsev, A.L. (2005). Estimating the parameters of the Arrhenius equation. Kinet. Catal. 46(3), 305-308. DOI: 10.1007/s10975-005-0077-9.

22. Schwaab, M. \& Pinto, J.C. (2007). Optimum reference temperature for reparameterization of the Arrhenius equation. Part 1: Problems involving one kinetic constant. Chem. Eng. Sci. 62(11), 2750-2764. DOI: 10.1016/j.ces.2008.03.010.

23. Sunberg, R. (1998). Statistical aspects on fitting the Arrhenius equation. Chemom. Intell. Lab. Sys. 41, 249-252. DOI: 10.1016/S0169-7439(98)00052-5.

24. Marquardt, D.W. (1963). An algorithm for least-squares estimation of nonlinear parameters. J. Soc. Ind. Appl. Math. 11, 431-441. http://www.dista.unibo.it/ bittelli/materiale_lettura_fisica_terreno/marquardt_63.pdf

25. Schleeger, M., Heberle, J. \& Kakorin, S. (2012). Simplifying the analysis of enzyme kinetics of cytochrome $c$ oxidase by the Lambert-W function. Open J. Biophysics 2, 117-129. DOI: 10.4236/ojbiphy.2012.24015.

26. Freitas, F.F., Marquez, L.D.S., Ribeiro, G.P., Brandão, G.C., Cardoso, V.L. \& Ribeiro, E.J. (2012). Optimization of the immobilization process of $\beta$-galatosidade by combined entrapment-cross-linking and the kinetics of lactose hydrolysis. Brazilian J. Chem. Eng. 29(01), 15-24. DOI: 10.1590/S010466322012000100002.

27. Sriyudthsak, K., Shiraishi, F. \& Hirai, M.Y. (2013). Identification of a metabolic reaction network from time-series data of metabolite concentrations. PLOS ONE 8(1) e51212, 1-9. DOI: 10.1371/journal.pone.0051212.

28. Costa, S.A. \& Reis, R.L. (2004). Immobilisation of catalase on the surface of biodegradable starch-based polymers as a way to change its surface characteristics. J. Mater. Sci.-Mater. Med. 15 (4), 335-342. DOI: 10.1023/B:JMSM.0000021098.75103.3a.

29. Gudelj, M., Fruhwirth, G.O., Paar, A., Lottspeich, F., Robra, K.H., Cavaco-Paulo, A. \& Gübitz, G.M. (2001). A catalase-peroxidase from a newly isolated thermoalkaliphilic Bacillus $s p$. with potential for the treatment of textile bleaching effluents. Extremophiles 5, 423-429. DOI: 10.1007/s007920100218.

30. Lorentzen, M.S., Moe, E.H., Jouve, M. \& Willassen, N.P. (2006). Cold adapted features of Vibrio salmonicida catalase: characterisation and comparison to the mesophilic counterpart from Prot. Mirab. Extrem. 10, 427-440. DOI: 10.1007/s00792006-0518-z.

31. Vasić-Rački, D., Findrik, Z. \& Presečki, A.V. (2011). Modelling as a tool of enzyme reaction engineering for enzyme reactor development. Appl. Microbiol. Biotechnol. 91(4), 845-856. DOI: 10.1007/s00253-011-3414-0.

32. Findrik, Z. \& Vasić-Rački, D. (2008). Mathematical modelling of amino acid resolution catalyzed by L-amino acid oxidases from Crotalus adamanteus and Crotalus atrox. Proc. Biochem. 43(11), 1186-1194. DOI: 10.1016/j.procbio.2008.06.010.

33. Grubecki, I. (2011). The optimal temperature control for the reactions with parallel deactivation of enzyme encapsulated inside microorganism cells. Comput. Methods Sci. Technol. 17(1-2), 25-34.34. https://www.man.poznan.pl/cmst/2011/17_1/ CMST17_12_03_Grubecki.pdf

34. Grubecki, I. \& Wójcik, M. (2006). Analysis of temperature policies for batch reactors with concentration independent catalyst deactivation. J. Chem. Eng. Jap. 39(10), 1065-1068. https://www.jstage.jst.go.jp/browse/jcej/39/10/_contents 